\title{
Changes in Forced Expiratory Volume in 1 Second over Time in COPD
}

\author{
Jørgen Vestbo, Dr.Med.Sc., Lisa D. Edwards, Ph.D., Paul D. Scanlon, M.D., \\ Julie C. Yates, B.S., Alvar Agusti, M.D., Ph.D., Per Bakke, Ph.D., \\ Peter M.A. Calverley, M.B., Ch.B., M.D., Bartolome Celli, M.D., \\ Harvey O. Coxson, Ph.D., Courtney Crim, M.D., David A. Lomas, M.D., Ph.D., \\ William MacNee, M.B., Ch.B., M.D., Bruce E. Miller, Ph.D., \\ Edwin K. Silverman, M.D., Ph.D., Ruth Tal-Singer, Ph.D., \\ Emiel Wouters, M.D., Ph.D., and Stephen I. Rennard, M.D., \\ for the ECLIPSE Investigators*
}

From the Respiratory Section, Hvidovre Hospital, Hvidovre, and the University of Copenhagen, Copenhagen - both in Denmark (J.V.); the Manchester Academic Health Sciences Centre, University of Manchester, Manchester (J.V.), the University of Liverpool, Liverpool (P.M.A.C.), the University of Cambridge, Cambridge (D.A.L.), and the University of Edinburgh, Edinburgh (W.M.) - all in the United Kingdom; GlaxoSmithKline, Research Triangle Park, NC (L.D.E., J.C.Y., C.C.), and King of Prussia, PA (B.E.M., R.T.-S.); the Mayo Clinic, Rochester, MN (P.D.S.); the Thorax Institute, Hospital Clinic, Institut d'Investigacions Biomèdiques August $\mathrm{Pi}$ i Sunyer, University of Barcelona, Barcelona, and CIBER Enfermedades Respiratorias, Palma, Mallorca - both in Spain (A.A.); the Institute of Internal Medicine, University of Bergen, Bergen, Norway (P.B.); Brigham and Women's Hospital and Harvard Medical School - both in Boston (B.C., E.K.S.); the University of British Columbia, Vancouver, Canada (H.O.C.); the University of Maastricht, Maastricht, the Netherlands (E.W.); and the University of Nebraska Medical Center, Omaha (S.I.R.). Address reprint requests to Dr. Vestbo at the Respiratory Section 253, Hvidovre Hospital, Kettegaard Alle 30, 2650 Hvidovre, Denmark, or at jvestbo@dadlnet.dk.

* Members of the Evaluation of COPD Longitudinally to Identify Predictive Surrogate Endpoints (ECLIPSE) steering and scientific committees and the study investigators are listed in the Supplementary Appendix, available at NEJM.org.

This article (10.1056/NEJMoal105482) was published on September 26, 2011, at NEJM .org.

N Engl J Med 2011;365:1184-92.

Copyright (๑) 2011 Massachusetts Medical Society.

\section{ABSTRACT}

\section{BACKGROUND}

A key feature of chronic obstructive pulmonary disease (COPD) is an accelerated rate of decline in forced expiratory volume in 1 second $\left(\mathrm{FEV}_{1}\right)$, but data on the variability and determinants of this change in patients who have established disease are scarce.

\section{METHODS}

We analyzed the changes in $\mathrm{FEV}_{1}$ after administration of a bronchodilator over a 3-year period in 2163 patients. A random-coefficient model was used to evaluate possible predictors of both $\mathrm{FEV}_{1}$ levels and their changes over time.

\section{RESULTS}

The mean $( \pm \mathrm{SE})$ rate of change in $\mathrm{FEV}_{1}$ was a decline of $33 \pm 2 \mathrm{ml}$ per year, with significant variation among the patients studied. The between-patient standard deviation for the rate of decline was $59 \mathrm{ml}$ per year. Over the 3-year study period, 38\% of patients had an estimated decline in $\mathrm{FEV}_{1}$ of more than $40 \mathrm{ml}$ per year, $31 \%$ had a decline of 21 to $40 \mathrm{ml}$ per year, $23 \%$ had a change in $\mathrm{FEV}_{1}$ that ranged from a decrease of $20 \mathrm{ml}$ per year to an increase of $20 \mathrm{ml}$ per year, and $8 \%$ had an increase of more than $20 \mathrm{ml}$ per year. The mean rate of decline in $\mathrm{FEV}_{1}$ was $21 \pm 4 \mathrm{ml}$ per year greater in current smokers than in current nonsmokers, $13 \pm 4 \mathrm{ml}$ per year greater in patients with emphysema than in those without emphysema, and $17 \pm 4 \mathrm{ml}$ per year greater in patients with bronchodilator reversibility than in those without reversibility.

\section{CONCLUSIONS}

The rate of change in $\mathrm{FEV}_{1}$ among patients with COPD is highly variable, with increased rates of decline among current smokers, patients with bronchodilator reversibility, and patients with emphysema. (Funded by GlaxoSmithKline; ECLIPSE ClinicalTrials.gov number, NCT00292552.) 
INCE THE SEMINAL STUDY BY FLETCHER et al. in the $1970 \mathrm{~s},{ }^{1,2}$ it has been widely accepted that chronic obstructive pulmonary disease (COPD) is characterized by an accelerated decline in forced expiratory volume in 1 second $\left(\mathrm{FEV}_{1}\right)$. However, surprisingly few longitudinal studies of patient cohorts have provided detailed data regarding the rate of decline in $\mathrm{FEV}_{1},{ }^{3-8}$ and none of these studies have related changes in $\mathrm{FEV}_{1}$ to specific subgroups of patients with COPD or to levels of systemic biomarkers. We used data from a large, observational, 3-year study that included detailed assessments of patients with COPD to examine the variability of changes in $\mathrm{FEV}_{1}$ and to explore whether these changes differed among patient subgroups and whether certain biomarkers could predict changes in $\mathrm{FEV}_{1}$.

\section{METHODS}

\section{STUDY DESIGN AND PATIENTS}

Our analysis was based on data collected in the Evaluation of COPD Longitudinally to Identify Predictive Surrogate Endpoints (ECLIPSE) observational study. ${ }^{9,10}$ Patients with COPD who were between the ages of 40 and 75 years were enrolled in the study if they had a history of 10 or more pack-years of smoking, as well as an $\mathrm{FEV}_{1}$ that was less than $80 \%$ of the predicted value and a ratio of $\mathrm{FEV}_{1}$ to forced vital capacity (FVC) of 0.7 or less; both measurements were made after use of a bronchodilator. Respiratory symptoms, smoking history, occupational exposure, and coexisting medical conditions were documented at study entry with the use of a modified version of the American Thoracic SocietyDivision of Lung Disease (ATS-DLD) questionnaire.

The study was conducted according to the Declaration of Helsinki and Good Clinical Practice guidelines. All patients provided written informed consent, and the study was approved by the relevant ethics and review boards. The study was conducted in accordance with the protocol, available with the full text of this article at NEJM.org.

\section{STUDY ASSESSMENTS}

After the baseline visit, patients returned to their study centers on seven occasions for follow-up assessments: at 3 months and at 6 months and then every 6 months for 3 years. At each visit, the patient reported the number of COPD exacerbations since the last visit. Exacerbations were defined as wors- ening of COPD symptoms that required treatment with antibiotics or systemic glucocorticoids, alone or in combination, or hospitalization, as reported in more detail previously. ${ }^{11}$ At each visit, the severity of COPD was graded according to the stages of disease as defined by the Global Initiative for Chronic Obstructive Lung Disease (GOLD). ${ }^{3}$

At baseline and at each subsequent visit, patients underwent spirometry (Viasys MasterScope) before and 15 minutes after inhaling $400 \mu \mathrm{g}$ of salbutamol from a metered-dose inhaler with the use of a Volumatic spacer (GlaxoSmithKline). Computed tomographic (CT) scanning of the chest was performed at baseline to evaluate the severity and distribution of emphysema. Quantitative assessment of lung volumes and estimation of the percentage of lung CT voxels below a threshold of -950 Hounsfield units was performed with the use of Pulmonary Workstation software, version 2.0 (VIDA Diagnostics). ${ }^{12}$

\section{SUBGROUPS AND BIOMARKERS}

Subgroups were based on status with respect to emphysema and chronic bronchitis, bronchodilator reversibility, and cardiovascular disease. Emphysema was defined as more than $10 \%$ of lung volume with a density of -950 Hounsfield units or less during a maximal inspiratory breath hold. Chronic bronchitis was defined as the presence of phlegm for periods of 3 months or more for at least 2 years and was assessed on the basis of responses to relevant ATS-DLD questions. Patients were classified as having either emphysema or chronic bronchitis, both entities, or neither entity. Bronchodilator reversibility was defined as an increase in $\mathrm{FEV}_{1}$ that was $12 \%$ above the baseline value and at least $200 \mathrm{ml}$ after inhalation of $400 \mu \mathrm{g}$ of albuterol. Patients were classified as having cardiovascular disease if they reported "heart trouble," hypertension, heart failure, or ischemic heart disease on the ATS-DLD questionnaire.

Serum and plasma samples for biomarker measurements were obtained at baseline and stored at $-80^{\circ} \mathrm{C}$ until they were analyzed. Relationships between changes in $\mathrm{FEV}_{1}$ and circulating levels of C-reactive protein, interleukin-8, interleukin-6, fibrinogen, tumor necrosis factor alpha, surfactant protein $\mathrm{D}$, and Clara cell secretory protein 16 (CC-16) were also measured. Details of the assays are described in the Supplementary Appendix, available at NEJM.org. 


\section{STATISTICAL ANALYSIS}

Random-coefficient models with both a random intercept and a random slope were constructed to determine the effect of patient characteristics on post-bronchodilator $\mathrm{FEV}_{1}$ at baseline and its rate of change over the 3-year study period. Quadratic and piecewise models with fixed and random join points (i.e., the points at which lines with different slopes meet) did not provide substantially better fit than did the linear model. The random slope was based on time of $\mathrm{FEV}_{1}$ assessment. The final predictors of baseline $\mathrm{FEV}_{1}$ (i.e., at the time of enrollment) and its rate of change were determined with the use of a series of models that were built up by means of stepwise selection of baseline clinical characteristics, phenotypes of interest, and biomarkers measured at study entry, as well as each covariate's interaction with time. Effect estimates were adjusted for age, sex, height, and weight at study entry; current smoking status and smoking history (pack-years) at study entry; and number of exacerbations during the year before entry. For nonsignificant terms in the models, effect estimates were the model coefficients just before removal from the model. The empirical Bayes estimate of the rate of change in $\mathrm{FEV}_{1}$ was calculated for each patient and summarized in the form of a histogram (Fig. 1). Comparisons of patient characteristics were carried out by means of analyses of variance, Kruskal-Wallis tests, or chi-square tests, as appropriate; t-tests based on the appropriate linear combinations of the random effects and their standard errors were used to compare the rates of change in $\mathrm{FEV}_{1}$. P values of less than 0.05 were considered to indicate statistical significance. No adjustments were made for multiple testing. All analyses were conducted with the use of SAS software, version 9.1 (SAS Institute). Additional details about model selection can be found in the Supplementary Appendix.

\section{RESULTS}

\section{PATIENT CHARACTERISTICS}

A total of 2164 patients were recruited for the study, 1 of whom was subsequently excluded because of inadequate $\mathrm{FEV}_{1}$ measurements for analyses. Of the remaining 2163 patients, 1447 had eight $\mathrm{FEV}_{1}$ assessments, 198 had seven, 95 had six, 99 had five, 96 had four, 81 had three, 67 had two, and 80 had only one. The baseline characteristics of the patients are reported in Table 1, categorized accord- ing to the number of $\mathrm{FEV}_{1}$ assessments available for evaluation. Patients with fewer measurements appeared to have more severe disease. Lung function at baseline was associated with age, sex, anthropometric measures, smoking history, and exacerbation history (Table 2). Table 1 in the Supplementary Appendix shows baseline characteristics of the patients according to geographic region.

\section{RATE OF CHANGE IN FEV}

The mean rate of change in $\mathrm{FEV}_{1}$ was a decline of $33 \pm 2 \mathrm{ml}$ per year, with significant variation in the levels of change (Fig. 1). The between-subjects standard deviation for the decline in $\mathrm{FEV}_{1}$ was $59 \mathrm{ml}$ per year. Slightly more than one in three participants (38\%) had an estimated rate of decline in $\mathrm{FEV}_{1}$ of more than $40 \mathrm{ml}$ per year over the 3-year period; in $31 \%, \mathrm{FEV}_{1}$ declined by 21 to $40 \mathrm{ml}$ per year, in $23 \%$ the change in $\mathrm{FEV}_{1}$ ranged from a decline of $20 \mathrm{ml}$ per year to an increase of $20 \mathrm{ml}$ per year, and in $8 \%, \mathrm{FEV}_{1}$ increased by more than $20 \mathrm{ml}$ per year. Patients with moderate disease (GOLD stage 2) had a mean rate of decline in $\mathrm{FEV}_{1}$ of $35 \pm 1 \mathrm{ml}$ per year, as compared with declines of $33 \pm 1 \mathrm{ml}$ per year in patients with severe disease (GOLD stage 3) and $25 \pm 2 \mathrm{ml}$ per year in patients with very severe disease (GOLD stage 4) ( $\mathrm{P}=0.17$ for stage 2 vs. stage 3 , $\mathrm{P}<0.001$ for stage 2 vs. stage $4, \mathrm{P}=0.009$ for stage 3 vs. stage 4 ).

The rate of change was not associated with the number of $\mathrm{FEV}_{1}$ measurements. The mean rate of decline for patients with seven or eight assessments was $32 \pm 1 \mathrm{ml}$ per year, as compared with $37 \pm 2 \mathrm{ml}$ per year for those contributing four, five, or six measurements and $31 \pm 3 \mathrm{ml}$ per year for those with one, two, or three measurements. Although $10 \%$ of the patients died and $13 \%$ withdrew from the study, the mean rates of change did not differ significantly among those who died, those who withdrew, and those who completed the study (Table 2 in the Supplementary Appendix). We did not see an increasing rate of decline with an increase in age or cumulative tobacco exposure, expressed as pack-years of smoking. Although men had higher levels of post-bronchodilator $\mathrm{FEV}_{1}$ at baseline, the rate of change was similar for men and women. The rate of decline in $\mathrm{FEV}_{1}$ was affected by smoking status, with a decline of $21 \pm 4 \mathrm{ml}$ per year more among current smokers than among former smokers. $\mathrm{FEV}_{1}$ at baseline was lower in patients who reported more exacerbations in the year before study entry, but 
the number of prior exacerbations had no effect on the subsequent rate of change. Exacerbations during follow-up, however, were associated with an excess decline in $\mathrm{FEV}_{1}$, with a mean loss of $2 \pm 0.5 \mathrm{ml}$ per year per exacerbation (Table 2 ).

\section{ANALYSIS OF SUBGROUPS}

Patients with chronic bronchitis did not have a more rapid rate of decline in $\mathrm{FEV}_{1}$ but did have a lower mean $\mathrm{FEV}_{1}(43 \pm 20 \mathrm{ml}$ per year) at baseline than did patients without chronic bronchitis. Patients with bronchodilator reversibility at baseline had a mean $\mathrm{FEV}_{1}$ that was $220 \pm 22 \mathrm{ml}$ per year higher than did patients without reversibility at baseline, and their $\mathrm{FEV}_{1}$ declined by an additional $17 \pm 4 \mathrm{ml}$ per year. The presence or absence of self-reported cardiovascular disease affected neither $\mathrm{FEV}_{1}$ at baseline nor its rate of change. In the subset of patients for whom CT data were available (1807 patients), the mean $\mathrm{FEV}_{1}$ at baseline was $327 \pm 21 \mathrm{ml}$ lower in those with clinically significant emphysema (>10\% low-attenuation areas) than in those with little or no emphysema, and $\mathrm{FEV}_{1}$ declined by an additional $13 \pm 4 \mathrm{ml}$ per year.

\section{ANALYSIS OF BIOMARKERS}

We analyzed data for the subset of patients for whom data on all biomarker values were available (1793 patients); the results of these analyses were not corrected for multiple testing. Several of the biomarkers we examined were associated with $\mathrm{FEV}_{1}$ at baseline (Table 3). This association was most pronounced for fibrinogen, for which the difference in $\mathrm{FEV}_{1}$ associated with an increase of $1 \mathrm{SD}$ was similar to the difference in $\mathrm{FEV}_{1}$ between current and former smokers. Only CC-16 levels were significantly associated with the rate of change in $\mathrm{FEV}_{1}$, with an additional decline of $4 \pm 2 \mathrm{ml}$ per year for each decrease of 1 SD in the level of CC-16. The association between the CC-16 level and the rate of decline in $\mathrm{FEV}_{1}$ was not modified by age, sex, GOLD stage, current smoking status or smoking history, or patient subgroup. Neither surfactant protein D nor any of the biomarkers believed to reflect systemic inflammation were related to a change in $\mathrm{FEV}_{1}$ over time (Table 3).

\section{DISCUSSION}

In this observational study of patients with COPD, we found that the rate of decline in $\mathrm{FEV}_{1}$ over a 3 -year period was highly variable. Although COPD

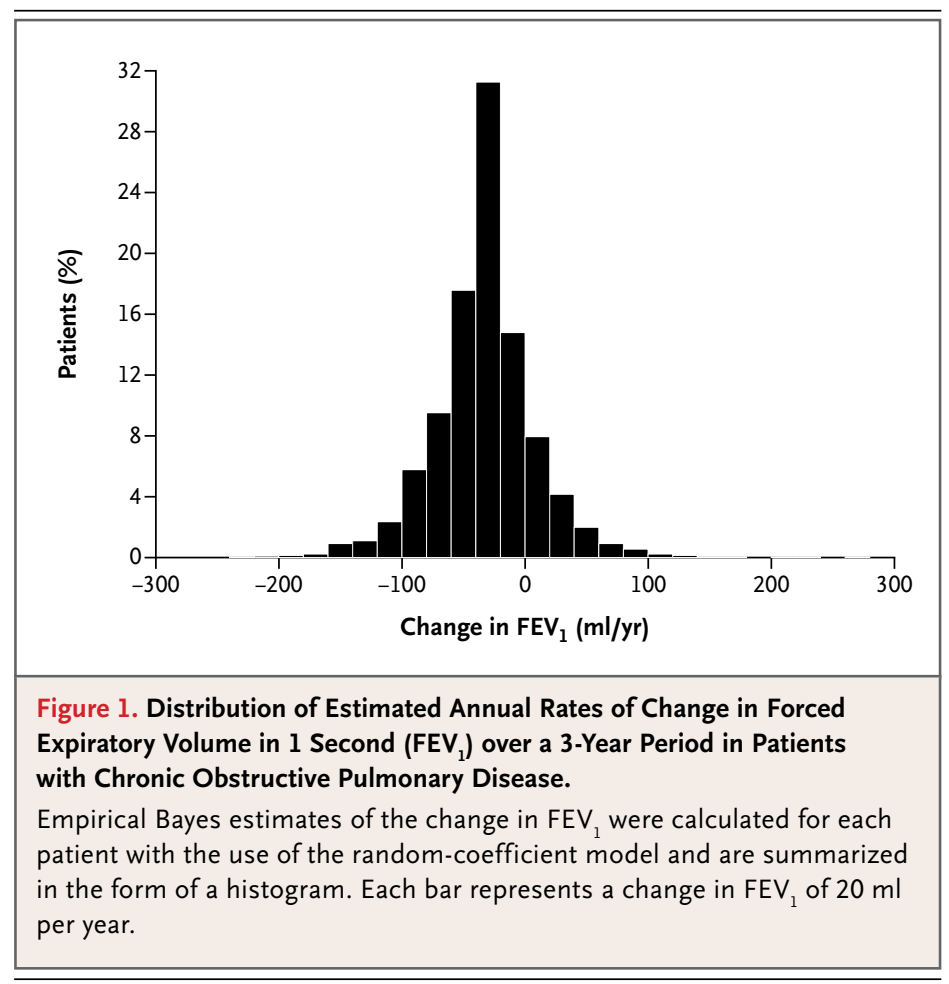

is considered to be a progressive disease, only $38 \%$ of patients had an estimated rate of decline in $\mathrm{FEV}_{1}$ of more than $40 \mathrm{ml}$ per year. Current smoking was most strongly associated with the rate of decline in $\mathrm{FEV}_{1}$. In addition, patients with emphysema (as defined on the basis of CT scanning) and patients with bronchodilator reversibility both had an excess loss of $\mathrm{FEV}_{1}$ over the 3-year study period, as compared with the study participants who did not have these conditions. None of the biomarkers were strongly associated with a decline in $\mathrm{FEV}_{1}$; however, the baseline level of CC-16 was associated with the rate of decline and may possibly serve as a biomarker of disease progression, if this finding can be replicated in other populations.

The relatively modest declines in lung function observed in the current study are not substantially different from those reported in the Understanding Potential Long-Term Impacts on Function with Tiotropium (UPLIFT) trial (ClinicalTrials.gov number, NCT00144339), in which the mean rate of decline in $\mathrm{FEV}_{1}$ over a period of 4 years was $41 \mathrm{ml}$ per year. ${ }^{8}$ In addition, when assessed according to the severity of airflow limitation, the rate of decline appears to be inversely related to the GOLD stage; this observation is consistent with the findings in both the UPLIFT study and the To- 
wards a Revolution in COPD Health (TORCH) study (ClinicalTrials.gov number, NCT00268216). ${ }^{7}$

Our study had several limitations. First, it included only patients with moderate, severe, or very severe COPD and thus cannot identify factors of importance that are associated with rates of decline in early-stage COPD. Epidemiologic studies have identified the presence of breathlessness ${ }^{13}$ and bronchial hyperreactivity ${ }^{14}$ as indicators of progressive loss of lung function, but recruitment for these studies and for ECLIPSE differed so much that a direct comparison is impossible.

Second, all the patients in our study received treatment for their COPD, which was managed by their usual physicians. Although none of the drugs available for the treatment of COPD have been shown unequivocally to reduce the decline in
$\mathrm{FEV}_{1},{ }^{3}$ a secondary analysis in the TORCH study indicated that declines in $\mathrm{FEV}_{1}$ may be reduced with regular treatment, ${ }^{15}$ and similar indications were evident in subgroup analyses in the UPLIFT trial. ${ }^{16}$ Our study was purely observational, and we chose not to include treatment in our analyses, since the effects of treatment on the rate of decline in $\mathrm{FEV}_{1}$ are likely to be confounded as a result of bias by indication and other biases that are characteristic of observational pharmacoepidemiologic studies. Moreover, the diagnosis and management of COPD in the patients in our study were carried out at specialist centers, and our results may not extend beyond this patient population for a variety of reasons, including the clinically determined care they received. An estimated $15 \%$ of the patients assessed in our study had

\begin{tabular}{|c|c|c|c|c|c|}
\hline \multirow[t]{2}{*}{ Characteristic } & \multirow[t]{2}{*}{$\begin{array}{l}\text { All Patients } \\
(\mathrm{N}=2163)\end{array}$} & \multicolumn{3}{|c|}{ No. of Assessments } & \multirow[t]{2}{*}{ P Value' } \\
\hline & & $\begin{array}{c}7 \text { or } 8 \\
(N=1645)\end{array}$ & $\begin{array}{c}4 \text { to } 6 \\
(N=290)\end{array}$ & $\begin{array}{c}1 \text { to } 3 \\
(\mathrm{~N}=228)\end{array}$ & \\
\hline Age (yr) & $63 \pm 7$ & $63 \pm 7$ & $65 \pm 7$ & $64 \pm 8$ & 0.001 \\
\hline Female sex (\%) & 35 & 35 & 33 & 34 & 0.80 \\
\hline \multicolumn{6}{|l|}{ Smoking status } \\
\hline Current smoker (\%) & 36 & 34 & 40 & 44 & 0.006 \\
\hline Smoking history (pack-yr) & $49 \pm 27$ & $48 \pm 27$ & $53 \pm 29$ & $51 \pm 27$ & 0.004 \\
\hline Body-mass indext & $27 \pm 6$ & $27 \pm 6$ & $26 \pm 6$ & $26 \pm 6$ & 0.46 \\
\hline \multicolumn{6}{|l|}{$\mathrm{FEV}_{1}$ after bronchodilator use } \\
\hline Value (liters) & $1.35 \pm 0.52$ & $1.39 \pm 0.52$ & $1.20 \pm 0.52$ & $1.21 \pm 0.50$ & $<0.001$ \\
\hline Percent of predicted value & $48 \pm 16$ & $50 \pm 16$ & $44 \pm 16$ & $44 \pm 15$ & $<0.001$ \\
\hline \multicolumn{6}{|l|}{ Exacerbations (no.) } \\
\hline In yr before study & $0.8 \pm 1.2$ & $0.8 \pm 1.1$ & $1.0 \pm 1.4$ & $0.9 \pm 1.3$ & 0.001 \\
\hline First yr of study & $1.2 \pm 1.5$ & $1.1 \pm 1.4$ & $1.7 \pm 2.0$ & $0.9 \pm 1.4$ & $<0.001$ \\
\hline \multicolumn{6}{|l|}{ Phenotype (\%) } \\
\hline Emphysema & 67 & 66 & 70 & 71 & 0.24 \\
\hline Chronic bronchitis & 35 & 34 & 38 & 39 & 0.12 \\
\hline Emphysema and chronic bronchitis & 22 & 21 & 23 & 24 & 0.56 \\
\hline Neither emphysema nor chronic bronchitis & 23 & 24 & 17 & 16 & 0.002 \\
\hline COPD and CVD & 56 & 54 & 60 & 59 & 0.09 \\
\hline \multicolumn{6}{|l|}{ Treatment (\%) } \\
\hline Inhaled glucocorticoids & 72 & 71 & 73 & 73 & 0.66 \\
\hline Long-acting beta-agonists & 68 & 68 & 70 & 67 & 0.62 \\
\hline Tiotropium & 46 & 46 & 49 & 42 & 0.22 \\
\hline
\end{tabular}




\begin{tabular}{|c|c|c|c|c|c|}
\hline \multirow[t]{2}{*}{ Characteristic } & \multirow[t]{2}{*}{$\begin{array}{l}\text { All Patients } \\
(\mathrm{N}=2163)\end{array}$} & \multicolumn{3}{|c|}{ No. of Assessments } & \multirow[t]{2}{*}{ P Value } \\
\hline & & $\begin{array}{c}7 \text { or } 8 \\
(N=1645)\end{array}$ & $\begin{array}{c}4 \text { to } 6 \\
(N=290)\end{array}$ & $\begin{array}{c}1 \text { to } 3 \\
(N=228)\end{array}$ & \\
\hline \multicolumn{6}{|l|}{ Biomarkers } \\
\hline C-reactive protein $(\mu \mathrm{g} / \mathrm{ml})$ & & & & & 0.07 \\
\hline Mean & 3.2 & 3.1 & 3.2 & 4.3 & \\
\hline Interquartile range & $1.5-7.3$ & $1.6-6.8$ & $1.5-7.9$ & $1.3-11.7$ & \\
\hline Interleukin-6 (pg/ml) & & & & & $<0.001$ \\
\hline Mean & 1.5 & 1.4 & 1.9 & 2.5 & \\
\hline Interquartile range & $0.8-3.1$ & $0.7-2.7$ & $0.9-3.9$ & $1.1-4.8$ & \\
\hline Interleukin-8 (pg/ml) & & & & & 0.015 \\
\hline Mean & 7.1 & 6.9 & 7.8 & 7.8 & \\
\hline Interquartile range & $3.4-13.2$ & $3.3-12.4$ & $3.6-17.3$ & $3.5-15.2$ & \\
\hline Fibrinogen (mg/dl) & & & & & 0.007 \\
\hline Mean & 449 & 444 & 465 & 456 & \\
\hline Interquartile range & $389-518$ & $388-512$ & $394-535$ & $391-541$ & \\
\hline TNF- $\alpha(\mathrm{pg} / \mathrm{ml})$ & & & & & 0.40 \\
\hline Mean & 2.4 & 2.4 & 2.4 & 2.4 & \\
\hline Interquartile range & $2.4-11.7$ & $2.4-15.2$ & $2.4-7.2$ & $2.4-2.4$ & \\
\hline CC-16 (ng/ml) & & & & & 0.26 \\
\hline Mean & 5.0 & 5.0 & 5.3 & 4.7 & \\
\hline Interquartile range & $3.5-7.0$ & $3.4-6.9$ & $3.7-7.5$ & $3.5-7.0$ & \\
\hline Surfactant protein $D(\mathrm{ng} / \mathrm{ml})$ & & & & & $<0.001$ \\
\hline Mean & 120 & 117 & 124 & 139 & \\
\hline Interquartile range & $84-172$ & $84-165$ & $83-188$ & $93-206$ & \\
\hline
\end{tabular}

* Plus-minus values are means \pm SD. CC-16 denotes Clara cell protein 16, COPD chronic obstructive pulmonary disease, CVD cardiovascular disease, and TNF- $\alpha$ tumor necrosis factor alpha.

$\uparrow P$ values are for the overall comparison of the three subject groups (determined by the number of assessments) and are based on analyses of variance, Kruskal-Wallis tests, and Cochran-Mantel-Haenszel tests, as appropriate.

$¥$ The body-mass index is the weight in kilograms divided by the square of the height in meters.

improved lung function over the 3-year study period. Whether this represents an expected statistical distribution or a true response to treatment is unknown. However, the possibility that some patients with COPD might have improvement over time was noted by Fletcher et al. ${ }^{2}$

Patients who continued to smoke were at increased risk for marked progression, as compared with former smokers, and this remained true irrespective of the GOLD stage. In contrast, cumulative exposure did not affect future decline. This finding points to smoking cessation as the most important tool in secondary and tertiary preven- tion for patients at all stages of COPD. ${ }^{1}$ Exacerbations had an effect on the rate of decline in $\mathrm{FEV}_{1}$, but this effect was very modest, as compared with the effect of smoking. The effect of exacerbations was also similar to that found in the Lung Health Study ${ }^{17}$ but was smaller than the effects in other studies $^{18,19}$; however, because studies differ considerably in design and inclusion criteria, direct comparisons are difficult. In our study, the association between bronchodilator reversibility and the rate of decline in $\mathrm{FEV}_{1}$ is more difficult to interpret. Reversibility is known to be an unstable phenomenon ${ }^{20}$ that does not predict mortality when post- 


\begin{tabular}{|c|c|c|c|c|}
\hline Characteristic & $\begin{array}{l}\text { Effect on Baseline } \\
\text { FEV }_{\mathbf{1}} \\
\mathrm{ml}\end{array}$ & P Value & $\begin{array}{l}\text { Effect on Annual Rate } \\
\text { of Change in FEV } \mathbf{1} \\
\mathrm{ml} / \mathrm{yr}\end{array}$ & P Value \\
\hline Age (per yr) & $-10 \pm 1.4$ & $<0.001$ & $0 \pm 0.3$ & 0.21 \\
\hline Female sex & $-55 \pm 26.0$ & 0.04 & $3 \pm 3.8$ & 0.42 \\
\hline Height (per cm) & $19 \pm 1.5$ & $<0.001$ & & \\
\hline Weight (per kg) & $5 \pm 0.6$ & $<0.001$ & & \\
\hline \multicolumn{5}{|l|}{ Smoking status } \\
\hline Current smoker (yes vs. no) & $102 \pm 20.7$ & $<0.001$ & $-21 \pm 3.8$ & $<0.001$ \\
\hline Smoking history (per pack-yr) & $-1 \pm 0.4$ & 0.02 & $0 \pm 0.1$ & 0.20 \\
\hline \multicolumn{5}{|l|}{ Prior exacerbations } \\
\hline$\geq 3$ vs. 0 & $-259 \pm 34.3$ & $<0.001$ & $-3 \pm 6.7$ & 0.67 \\
\hline$\geq 3$ vs. 1 & $-107 \pm 37.1$ & 0.004 & $2 \pm 7.2$ & 0.83 \\
\hline$\geq 3$ vs. 2 & $-47 \pm 41.6$ & 0.25 & $-5 \pm 8.1$ & 0.57 \\
\hline Exacerbations during follow-up (per exacerbation) & & & $-2 \pm 0.5$ & $<0.001$ \\
\hline Bronchodilator reversibility (yes vs. no) & $220 \pm 22.4$ & $<0.001$ & $-17 \pm 4.2$ & $<0.001$ \\
\hline Emphysema (yes vs. no) & $-327 \pm 21.2$ & $<0.001$ & $-13 \pm 4.2$ & 0.002 \\
\hline Chronic bronchitis (yes vs. no) & $-43 \pm 20.2$ & 0.033 & $-2 \pm 3.8$ & 0.67 \\
\hline Cardiovascular disease (yes vs. no) & $11 \pm 19.7$ & 0.57 & $1 \pm 3.6$ & 0.77 \\
\hline
\end{tabular}

* Plus-minus values are means \pm SE.

\begin{tabular}{|c|c|c|c|c|}
\hline Biomarkerì & $\begin{array}{l}\text { Effect on Baseline } \\
\text { FEV }_{\mathbf{1}} \\
\mathrm{ml}\end{array}$ & P Value & $\begin{array}{c}\text { Effect on Annual Rate } \\
\text { of Change in } \mathrm{FEV}_{\mathbf{1}} \\
\mathrm{ml} / \mathrm{\gamma r}\end{array}$ & P Value \\
\hline Fibrinogen & $-93 \pm 10.6$ & $<0.001$ & $-1 \pm 2.1$ & 0.63 \\
\hline Interleukin-6 & $0 \pm 10.0$ & $>0.99$ & $1 \pm 2.3$ & 0.52 \\
\hline Interleukin-8 & $20 \pm 9.9$ & 0.04 & $-2 \pm 2.0$ & 0.36 \\
\hline TNF- $\alpha$ & $1 \pm 9.9$ & 0.89 & $0 \pm 1.8$ & 0.84 \\
\hline C-reactive protein & $-23 \pm 10.3$ & 0.037 & $4 \pm 2.1$ & 0.07 \\
\hline CC-16 & $33 \pm 10.8$ & 0.002 & $4 \pm 2.2$ & 0.04 \\
\hline Surfactant protein D & $0 \pm 10.3$ & 0.96 & $-3 \pm 2.1$ & 0.18 \\
\hline
\end{tabular}

$*$ Plus-minus values are means $\pm \mathrm{SE}$.

$\dagger$ Effects are per increase of 1 SD in the values of the individual biomarkers (i.e., a change of 1 SD in the level of the biomarker resulted in a specific effect on $\mathrm{FEV}_{1}$ ). CC-16 denotes Clara cell protein 16, and TNF- $\alpha$ tumor necrosis factor alpha. $\lceil P$ values were not corrected for multiple testing.

bronchodilator $\mathrm{FEV}_{1}$ is taken into account. ${ }^{21}$ Fur- between reversibility and rate of decline. ${ }^{20,22}$ Our thermore, analyses of the larger Lung Health Study, definition of reversibility, which included both a which involved patients who had milder disease relative and an absolute criterion, may have led than the patients in our study, and the smaller In- to the association we observed - a possibility haled Steroids in Obstructive Lung Disease in Eu- that should be examined in replication studies. rope (ISOLDE) study, which involved patients with We studied a number of biomarkers and found more severe disease, did not show an association that only one, CC-16, was associated with the rate 
of decline in $\mathrm{FEV}_{1}$. This association was weak, and whether it is biologically meaningful has yet to be determined. Without confirmation, it does not seem appropriate to speculate on the potential significance of this finding. The list of potentially valuable biomarkers is long ${ }^{23}$ and growing. Other markers will undoubtedly be tested in other studies.

In conclusion, our data show that COPD is not invariably progressive. In more than half the patients in our study, the rate of decline in $\mathrm{FEV}_{1}$ over a period of 3 years was no greater than that which has been observed in people without lung disease. This finding could indicate that COPD may "burn out" or at least stabilize for periods of 3 years or more, which would be good news for patients and could influence a variety of management decisions that depend on prognosis. The continuation of smoking is strongly associated with an increased rate of decline in $\mathrm{FEV}_{1}$, a finding that underscores the importance of smoking cessation for patients with this condition. Since our findings challenge the concept that progressive loss of lung function is inevitable in COPD, they should spark interest in revising our view of the course of this condition.

Supported by grants from GlaxoSmithKline (to Drs. Vestbo, Scanlon, Agusti, Bakke, Calverley, Celli, Coxson, Lomas, MacNee, Silverman, Wouters, and Rennard).

Dr. Vestbo reports receiving consulting fees from AstraZeneca, Boehringer Ingelheim, Chiesi, GlaxoSmithKline, Novartis, Nycomed, and Pfizer, speaking fees from AstraZeneca, Boehringer Ingelheim, GlaxoSmithKline, Novartis, and Nycomed, and grants on behalf of his institution from GlaxoSmithKline; Dr. Scanlon, receiving travel support from Boehringer Ingelheim and Novartis and receiving grants from Boehringer Ingelheim, Forest Laboratories, GlaxoSmithKline, Pfizer, and Novartis on behalf of his institution; Dr. Agusti, receiving fees for serving on the boards of Almirall, AstraZeneca, Boehringer Ingelheim, Esteve, GlaxoSmithKline, Novartis, Nycomed, and Roche, speaking fees from Almirall, AstraZeneca, Boehringer Ingelheim, Esteve, GlaxoSmithKline, and Nycomed, payment for the development of educational presentations from Nycomed, and receiving grants from Almirall, GlaxoSmithKline, and Nycomed on behalf of his institution; Dr. Bakke, receiving speaking fees from AstraZeneca, GlaxoSmithKline, and Pfizer; Dr. Calverley, receiving fees for serving on the boards of GlaxoSmithKline, Boehringer Ingelheim, and Nycomed, consulting fees from Merck and Novartis, payment for providing expert testimony for Forest, speaking fees from AstraZeneca and GlaxoSmithKline, travel support from Boehringer Ingelheim, and receiving speaking fees from Novar- tis and Pfizer on behalf of his institution; Dr. Celli, receiving consulting fees from Aeris, Almirall, AstraZeneca, Boehringer Ingelheim, Novartis, and Rox Medical; Dr. Coxson, receiving consulting fees from GlaxoSmithKline and Spiration, speaking fees from AstraZeneca, travel support from AstraZeneca and Spiration, and receiving grants from GlaxoSmithKline and Spiration on behalf of his institution; Dr. Lomas, receiving fees for serving on the board of GlaxoSmithKline, consulting fees from GlaxoSmithKline, speaking fees from GlaxoSmithKline, travel support from Boehringer Ingelheim and GlaxoSmithKline, and receiving grants from GlaxoSmithKline on behalf of his institution; Dr. MacNee, receiving travel support from AstraZeneca, Boehringer Ingelheim, GlaxoSmithKline, and Pfizer, and he and his institution receiving consulting fees from Pfizer and fees for membership on the boards of Pfizer and GlaxoSmithKline; Dr. Rennard, receiving fees for membership on the boards of Almirall, Novartis, Nycomed, and Pfizer, consulting fees from Able Associates, Adelphi Research, APT Pharma/Britnall, Aradigm, AstraZeneca, Boehringer Ingelheim, Chiesi, CommonHealth, Consult Complete, COPDforum, Datamonitor, Decision Resources, Defined Health, Dey, Dunn Group, Easton Associates, Equinox, Forest, Gerson, GlaxoSmithKline, InfoMed, KOL Connection, M. Pankove, MedaCorp, MDRx Financial, Mpex, Novartis, Nycomed, Oriel Therapeutics, Otsuka, Pennside, Parma Ventures, Pearl, Pharmaxis, Price Waterhouse, Propagate, Pulmatrix, Reckner Associates, Recruiting Resources, Roche, Sankyo, Schlesinger Medical, Scimed, Sudler and Hennessey, TargeGen, Theravance, United BioSource, Uptake Medical, and VantagePoint Management, speaking fees from AstraZeneca, Convergent Health Solutions for Reviews and Trends in COPD, COPD Foundation, Creative Educational Concepts, Dey, France Foundation, Information TV, Network for Continuing Education (CHARM), Novartis (Horsham), Nycomed, Otsuka, and Pfizer, travel support from Almirall, AstraZeneca, Boehringer Ingelheim, California Allergy Society, Creative Educational Concept, France Foundation, GlaxoSmithKline, Information TV, Network for Continuing Education, Novartis, Nycomed, and Pfizer, and receiving grants from AstraZeneca, Biomarck, Boehringer Ingelheim, Centocor, Mpex, Nabi, Novartis, Nycomed, and Otsuka on behalf of his institution; Dr. Silverman, receiving consulting fees from AstraZeneca and GlaxoSmithKline, speaking fees from AstraZeneca and GlaxoSmithKline, and receiving grants from GlaxoSmithKline on behalf of his institution; and Dr. Wouters, receiving fees for membership on the board of Nycomed, speaking fees from AstraZeneca, GlaxoSmithKline, and Novartis, and grants from AstraZeneca and GlaxoSmithKline. Drs. Crim, Edwards, Miller, Tal-Singer, and Yates report being employees of and owning stock in GlaxoSmithKline. No other potential conflict of interest relevant to this article was reported.

Disclosure forms provided by the authors are available with the full text of this article at NEJM.org.

We thank all the study participants for their willingness to advance medical science in the field of COPD, Drs. Nestor Müller and Paola Nasute Fauerbach for their radiologic expertise in the assessment of emphysema, and Tara Candido, Sebastian Cogswell, Heather Davis, Nima Farzaneh, Lukas Holy, Natasha Krowchuk, Helena Lee, Evan Phillips, Claudine Storness-Bliss, Nerissa Tai, Anh-Toan Tran, Nghia Tran, Eugene Wang, and Tomonori Yokogawa for technical assistance with the CT analysis and data management.
REFERENCES

1. Fletcher C, Peto R. The natural history of chronic airflow obstruction. BMJ 1977; 1:1645-8.

2. Fletcher $\mathrm{CM}$, Peto $\mathrm{R}$, Tinker $\mathrm{CM}$, Speizer FE. The natural history of chronic bronchitis and emphysema. Oxford, England: Oxford University Press, 1976.
3. Global Initiative for Chronic Obstructive Lung Disease. Global strategy for diagnosis, management, and prevention of COPD. (http://www.goldcopd.org/guidelines -global-strategy-for-diagnosis-management .html.)

4. Antó JM, Vermeire P, Vestbo J, Sunyer
J. Epidemiology of chronic obstructive pulmonary disease. Eur Respir J 2001; 17:982-94.

5. Viegi G, Pistelli F, Sherrill DL, Maio S, Baldacci S, Carrozzi L. Definition, epidemiology and natural history of COPD. Eur Respir J 2007;30:993-1013. 
6. Raherison C, Girodet PO. Epidemiology of COPD. Eur Respir Rev 2009;18:21321.

7. Jenkins CR, Jones PW, Calverley PMA, et al. Efficacy of salmeterol/fluticasone propionate by GOLD stage of chronic obstructive pulmonary disease: analysis from the randomised, placebo-controlled TORCH study. Respir Res 2009;10:59.

8. Tashkin DP, Celli B, Senn S, et al. A 4-year trial of tiotropium in chronic obstructive pulmonary disease. N Engl J Med 2008;359:1543-54

9. Vestbo J, Anderson W, Coxson HO, et al. Evaluation of COPD Longitudinally to Identify Predictive Surrogate End-points (ECLIPSE). Eur Respir J 2008;31:869-73.

10. Agustí A, Calverley PMA, Celli B, et al. Characterization of COPD heterogeneity in the ECLIPSE cohort. Respir Res 2010; 11:122.

11. Hurst JR, Vestbo J, Anzueto A, et al. Susceptibility to exacerbation in chronic obstructive pulmonary disease. N Engl J Med 2010;363:1128-38.

12. Gietema HA, Müller NL, Fauerbach $\mathrm{PV}$, et al. Quantifying the extent of emphysema: factors associated with radiologists' estimations and quantitative indices of emphysema severity using the ECLIPSE cohort. Acad Radiol 2011;18:66171.
13. Bridevaux PO, Gerbase MW, ProbstHensch NM, Schindler C, Gaspoz JM, Rochat $\mathrm{T}$. Long-term decline in lung function, utilisation of care and quality of life in modified GOLD stage 1 COPD. Thorax 2008;63:768-74.

14. Brutsche MH, Downs SH, Schindler C et al. Bronchial hyperresponsiveness and the development of asthma and COPD in asymptomatic individuals: SAPALDIA cohort study. Thorax 2006;61:671-7.

15. Celli BR, Thomas NE, Anderson JA, et al. Effect of pharmacotherapy on rate of decline of lung function in chronic obstructive pulmonary disease: results from the TORCH study. Am J Respir Crit Care Med 2008;178:332-8.

16. Decramer M, Celli B, Kesten S, Lystig T, Mehra S, Tashkin DP. Effect of tiotropium on outcomes in patients with moderate chronic obstructive pulmonary disease (UPLIFT): a prespecified subgroup analysis of a randomised controlled trial. Lancet 2009;374:1171-8.

17. Kanner RE, Anthonisen NR, Connet JE. Lower respiratory illnesses promote $\mathrm{FEV}_{1}$ decline in current smokers but not ex-smokers with mild chronic obstructive pulmonary disease: results from the Lung Health Study. Am J Respir Crit Care Med 2001;164:358-64.

18. Donaldson GC, Seemungal TAR,
Bhowmik A, Wedzicha JA. Relationship between exacerbation frequency and lung function decline in chronic obstructive pulmonary disease. Thorax 2002;57:84752. [Erratum, Thorax 2008;63:753.]

19. Calverley PMA, Anderson JA, Celli B, et al. Salmeterol and fluticasone propionate and survival in chronic obstructive pulmonary disease. N Engl J Med 2007; 356:775-89.

20. Calverley PM, Burge PS, Spencer S, Anderson JA, Jones PW. Bronchodilator reversibility testing in chronic obstructive pulmonary disease. Thorax 2003;58:65964.

21. Hansen EF, Phanareth K, Laursen LC, Kok-Jensen A, Dirksen A. Reversible and irreversible airflow obstruction as predictor of overall mortality in asthma and chronic obstructive pulmonary disease. Am J Respir Crit Care Med 1999;159:126771.

22. Anthonisen NR, Lindgren PG, Tashkin DP, Kanner RE, Scanlon PD, Connett JE. Bronchodilator response in the Lung Health Study over 11 years. Eur Respir J 2005;26:45-51.

23. Sin D, Vestbo J. Biomarkers in chronic obstructive pulmonary disease. Proc Am Thorac Soc 2009;6:543-5.

Copyright (๑) 2011 Massachusetts Medical Society.

AN NEJM APP FOR IPHONE

The NEJM Image Challenge app brings a popular online feature to the smartphone. Optimized for viewing on the iPhone and iPod Touch, the Image Challenge app lets you test your diagnostic skills anytime, anywhere. The Image Challenge app randomly selects from 300 challenging clinical photos published in NEJM, with a new image added each week. View an image, choose your answer, get immediate feedback, and see how others answered.

The Image Challenge app is available at the iTunes App Store. 